\title{
VÁLASZ BUJTOR LÁSZLÓ MEGJEGYZÉSEK EMBEY-ISZTIN ANTAL AZ ÉREM MÁSIK OLDALA CÍMŨ TANULMÁNYÁHOZ
}

\section{REFLECTIONS ON LÁSZLÓ BUJTOR'S REMARKS TO ANTAL EMBEY-ISZTIN'S PAPER THE OTHER SIDE OF THE COIN}

\author{
Embey-Isztin Antal \\ DSc, társult kutató, Magyar Természettudományi Múzeum Ásvány- és Kőzettár, Budapest \\ embey@nhmus.hu
}

ÖSSZEFOGLALÁS

Ez a válasz néhány fontos kérdést hangsúlyoz, mint amilyen a modern lemeztektonikai rezsim kezdetének időpontja; a szibériai trappbazalt erupciók meghatározó szerepe a perm-végi tömeges kihalási eseményben; a kambriumi robbanás egyedülálló volta az élet történetében és az „eukarióta forradalom” kifejezés jogosultsága, mint ami kezdőpontja minden modern többsejtes életforma kialakulásának, magunkat is beleértve.

\section{ABSTRACT}

In the present reflections a few important ideas have been underlined, such as the timing of initiation of the modern plate tectonic regime; the crucial role of the Siberian trap basalt eruptions in the end-Permian mass extinction; the uniqueness of the Cambrian explosion in the history of life and justifying of the use of the term of 'eukaryotic revolution' as the origin of all forms of modern multicellular life, including us.

Kulcsszavak: modern lemeztektonika, bazalt vulkanizmus, perm-végi kihalás, kambriumi robbanás, eukarióta forradalom

Keywords: modern plate tectonics, basaltic volcanism, end-Permian extinction, Cambrian explosion, eukaryotic revolution

Először is köszönettel tartozom Bujtor Lászlónak, mert számos érdekes részlettel és szemponttal egészítette ki a mondanivalómat. Ezek egy kis részének említését magam is terveztem, de a folyóirat terjedelmi korlátait nem akartam túllépni. Most sem szeretném hosszúra nyújtani a mondanivalómat, ezért csak néhány 
olyan pontra térnék ki, amelyek segíthetik az olvasót pár vitatatható kérdés tisztánlátásában.

1. „A lemeztektonika megjelenése és folyamatai csaknem egyidősek a szilárd, szárazföldi kéreg megjelenésével."

Ez ma már erősen vitatott álláspont, és egyre többen vallják, hogy az Archaikumban és föleg annak első felében a modern lemeztektonika nem múködött, például: Debaille et al., 2013; Bédard, 2018; Beall et al., 2018.

2. „Mégis csupán az utolsó, a Pangea-konfiguráció az, amelynek kialakulásához az egyik legnagyobb kihalási eseményt társítjuk."

Az biztos, hogy a Pangea nagyon kemény kihívást jelentett az élet számára, mely sok faj kihalásával járt. Az viszont mára már szinte dogma, hogy a perm-triász határon bekövetkezett tömeges kihalást az elképesztő mennyiségü szibériai trappbazalt-kitörések okozták.

3. „A kambriumi robbanás unikum volt a Föld történetében. Hivatkozott írásomban (Bujtor, 2020) részletezem, hogy mai tudásunk alapján nem maga a kambriumi életrobbanás a meglepő, azt ma már jóval inkább korábbi folyamatok elkerülhetetlen következményeként látjuk."

Darwinnal szemben, akinek ez sok fejtörést okozott, mi persze tudjuk, hogy az élet közel négymilliárd éves, és az Ediakara-bióta is megelőzte az 540 millió éves eseményt. De ez utóbbi mibenlétét nem ismerjük, és az Ediakara-bióta utódok nélkül tủnt el a fosszilis rekordból. Ilyen értelemben, a törzsi szinten ma is létező élet hirtelen megjelenése a kambriumban mégiscsak unikum.

4. „2. ábra, a primitív állati élet kialakulásának ideje. Az ábra forrásaként megadott oldal felkeresése nem sikerült, így az eredeti ábrát nem találtam meg. Az ábra mindenesetre azt sugallja, hogy a »primitív állati élet« valamikor a kambriumi életrobbanással együtt jelent meg. Ez téves. A kriogén időszakot követően már ismerünk többsejtü, bonyolult testfelépítésü lényeket az Ediakara-faunából (például Dickinsonia), melyek már 800-900 millió évvel ezelött megjelentek, és igen hosszú időn keresztül virágoztak.”

Sajnos az eredeti ábra közlésének jogát nem tudtam megszerezni. Az átrajzolt ábrán, a 15 milliárd éves skálán, ilyen méretben, a primitív állati élet megjelenését jelző háromszög kb. jó helyre került, az 540 millió éves kambriumi esemény ábrázolásához itt már hely sem lenne.

5. „Az eukarióta evolúciós forradalom volt a döntő előrelépés, amely az állatvilág megjelenésében kulminált.” „Ezzel a megjegyzéssel ebben a megfogalmazásban nem értek egyet. Az eukarióta sejt (= sejtmaggal rendelkező sejt) megjelenése 
önmagában nem lett volna elegendő ahhoz a sokszínü, bonyolult és soksejtes élővilágnak a kifejlődéséhez, amint ezt a fenti mondat sugallja."

Természetesen nagyon sok faktor járult hozzá a sokszínü eukarióta élővilág kialakulásához, beleértve az ember megjelenését is, de ennek részletezése nem volt és nem is lehetett célja a jelen tanulmánynak, már csak a terjedelmi korlátok miatt sem. Azonban az is kétségtelen, hogy mindezek kiindulópontja a valódi sejtmaggal rendelkező sejtek megjelenése volt, amit egy kb. 1000 millió évig tartó prokarióta időszak előzött meg. Ilyen értelemben szokás eukarióta forradalomról beszélni.

\section{IRODALOM}

Beall, A. P. - Moresi, L. - Cooper, C. M. (2018): Formation of Cratonic Lithosphere during the Initiation of Plate Tectonics. Geology, 46, 6, 487-490. DOI: 10.1130/G39943.1, https://pdfs. semanticscholar.org/723c/6264cbf85c477f8e3dcafd51a04eff1c3f7b.pdf

Bédard, J. H. (2018): Stagnant Lids and Mantle Overturns: Implications for Archaean Tectonics, Magmagenesis, Crustal Growth, Mantle Evolution, and the Start of Plate Tectonics. Geoscience Frontiers, 9, 1, 19-49. DOI: 10.1016/j.gsf.2017.01.005, https://www.sciencedirect.com/science/ article/pii/S1674987117300233

Debaille, V. - O'Neill, C. - Brandon, A. D. et al. (2013): Stagnant-lid Tectonics in Early Earth Revealed by ${ }^{142} \mathrm{Nd}$ Variations in Late Archean Rocks. Earth and Planetary Science Letters, 373 , 83-92. DOI: 10.1016/j.eps1.2013.04.016, https://bit.ly/2NyOU4w 